денный преступникь“, симулировавшій фетишизмы для выманиванія денегт п для того, чтобы избъгнуть наказанія.

I думаю, что мы должны быть благодарны Kurella, как' первому из' германскихь психіатровь, прямо высказавшему; что дйетвите.пно есть преступниии-люди ненормальные, но

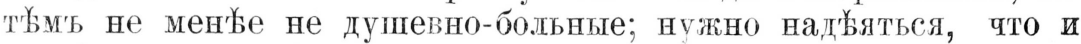
другіе психіатры вт свопхь заґлюченіяхь у судебныхь сль্-

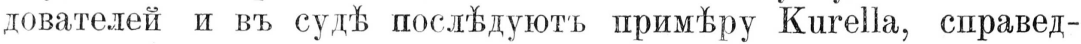
ливо разсуждающему, что выводъ изъ такой экспертизы, какъ и изт всякой, подлежить сдилать сүду.

\title{
B. $Y$.
}

Ferrari. Психическія разстройства въ сочетаніи сь множественнымт невритомь. (Cerebropathia psychica toxaemica Kорсакова, Polyneuritis Psychosis другихь авторовь).- The Alienist and Neurologist, January 1896, № 1.

Подь пменемь Polyneuritis psychosis Ropcaґов'ь описал'ь бол’знь, отличающюся оть типичнаго полиневрита преобладаніемь разстройствь со стороны психической сферы. Начинается она соматическими симптомоми-рвотой, затрудненной походкой, болями и мышечной атрофіей; электровозбудимость мыпць пропадаеть, являются контрактуры; кол'енный рефолексь рано исчезаеть, другіе остаются нормальными или даже повышенными. Смерть наступаеть оть паралича пыхательныхъ мышць. Что гасается психическихь разстройствъ, то посл首днія про-

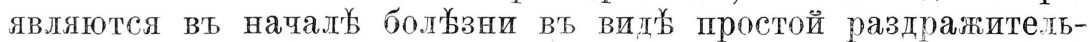
ности, впосл官дствіи же на первый плань выступаеть атnеsia. Посльвдняя развивается медленно, но, разь развившись, обыкновенно весьма рбзко выражена и удерживается долгое время. Иногда замбчають разстройства со стороны головного и спинного мозга: нарушеніе ръчи, глотанія, nystagmus, наружная офтальмоплегія. Больной на первый взглядь кажется вполне нор нолальнымь : разумно разсуждаеть, даже съ одушевленіемъ, но весьма быстро забываеть, что случилось

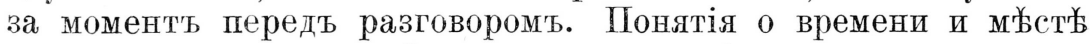
отсутствують; при извъстномь напряженіи силы воли мозжетъ даже обнаружиться нйкоторая память, но не надолго.

Что касается анатомическихь основъ описываемой бол'6зни, то въ одномъ случағ Gies'a и Pagenstecher'a найденш были капиллярныя кровопзліянія въ головномъ мозгу; авторь 
однако не придаеть имь значенія, такь какь больной бығ әпилептикь. Вь продолговатомь мозгу были находимы вакуолы въ нервныхь кльткахь, в' периферическихь нервахь частичный (Segmentary) неврить по типу Gombault, в'ь мышцахь-перерожденіе волоконь. Вь случағ Корсакова и Сербскаго въ продолговатомь мозгу было констатировано вь сто.ібахь Голля и боковыхь разсьянное разростаніе неврогліи.Этіологія больвни такая же, какъ и множественнаго неврита; причины ея - интоксикаціи (свинець, мышьякь, алкоголь) и токсэмія, обусловленная особымь ядомт) (неизвесстной химической природы), выд它ляемымь, в安роятно, микроорганизмами. Дифференціальный діагнозь должень именть въ виду истерію, поліоміэлить и острый восходящій параличь. П̈рогнозь обыкновенно благопріятень и зависить вь общемт оть интенсивности общихь симптомовь. Јеченіе-профилактическое и симптоматическое.

Анализируя описанную картину, авторь останавливается на амнезіи, какь бормег, признанной авторами характерной для polyneuritis psychosis. Но амнезія встрбччается и при друГихь страданіяхь: 1) при множественномь неврите на почвь алкоголизма; 2) при множественномь неврит年, вызванномь иными моментами, 3) при алкогопиме, не сопровождающемся нервными разстройствами , 4) въ т歺хь случаяхь, когда существують

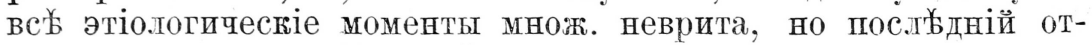

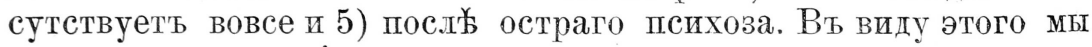
не можемь амневію относить ни кь множ. невриту, ни кь а.ґоголизму, такь какъ ея нељть при наличности названныхь условій. Вообще психич. разстройства, сопровождающія полиневрить, слишкомь скоропреходящи, чтобы принимать ихь за посль্ьцствія множественнаго неврита, такь что правильнье было бы разсматривать психическія разстройства, сопутствующія полиневриту, за явленія случайныя. Нераціонально поэтому, въ виту крайне незначительнаго числа наблюденій, создавать новую больвнь.

$$
\text { I. X. }
$$

Harriet $C$. B. Alexander.-Abuse of bromides.-The Alienist and Neurologist, 1896, № 3.

Авторь собраль важньйшія наблюденія, касающіяся побочнаго дейеистія бромистыхъ препаратовь, употребляемыхъ въ большихь дозахь. Чаще всего пора-

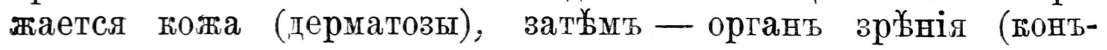

